\title{
THE IMPACT OF TEAM DIVERSITY, TASK INTERDEPENDENCE, TEAM CONFLICT AND TEAM COOPERATION ON JOB PERFORMANCE: USING REAL ESTATE BROKERS AS EXAMPLES
}

\author{
Chun-Chang Lee ${ }^{1}$--- Yu-Hsuan Lee ${ }^{2}$--- Hsiao-Han Chen ${ }^{3}$--- Pei-Shan Hsieh ${ }^{4}$--- Yung-Yun \\ Yeh $^{5}$--- Mei-Chu Lin ${ }^{6}$ \\ ${ }^{\prime}$ Associate professor, Department of Real Estate Management, National Pingtung Institute of Commerce, Taiwan, \\ ROC Mingsheng East Road, Pingtung, Taiwan \\ ${ }_{2,3,4,5,6}$ Graduated from the Department of Real Estate Management, National Pingtung Institute of Commerce, Taiwan, \\ ROC Mingsheng East Road, Pingtung, Taiwan
}

\begin{abstract}
This study investigated the impact of team diversity, task interdependence, team conflict, and team cooperation on job performance. The research subjects were real estate brokers in Kaohsiung City, Taiwan, and the results were measured by a linear structural model. A total of 568 questionnaires were distributed, of which367 were retrieved. After eliminating the invalid samples, 362 valid questionnaires remained, with a valid return rate of $98.64 \%$. According to the empirical results of the study, the following conclusions can be drawn: team diversity positively and significantly influences task conflict and relationship conflict; task interdependence positively and significantly influences job performance and team cooperation; task interdependence negatively and significantly influences relationship conflict; relationship conflict negatively and significantly influences team cooperation; and team cooperation positively and significantly influences job performance. In addition, team diversity and task interdependence were found to be critical exogenous factors ofjob performance.
\end{abstract}

Keywords: Team diversity, Task conflict, Relationship conflict, Task interdependence, Team cooperation, Job performance. 


\section{Contribution/ Originality}

This study treats team diversity and task interdependence as exogenous variables and combines them with the job performance model. The empirical results of this study indicate good explanatory power. The results of our study suggest that managers of real estate companies should focus on the impact of team diversity and relationship conflict on job performance. Likewise, real estate industries should enhance task interdependence, because it increases team cooperation and lowers relationship conflict.

\section{INTRODUCTION}

In research on teams, team diversity has been a central topic in recent years. In response to the challenges of globalization, enterprises must enhance competitiveness and human resources. Hence, the job performance of team members of different genders, ages, educational levels, professional capacities, and work backgrounds must be upgraded. When team diversity is higher, enterprises encounter the issue of how to effectively manage diversity and increase job performance.

Therefore, the problem-solving capacity of teams must be enhanced in order to improve productivity and work efficiency, decrease costs, use resources efficiently, and obtain higher performance using less manpower (Wellins et al., 1994). Johnson and Johnson (1989) generalized the advantages of team interdependence, including the enhancement of learning, achievements, cognitive complexity, and interpersonal relationships.

The work of real estate brokers emphasizes personal performance and individualism. However, some direct-selling stores and franchise companies encourage real estate brokers to work in teams by providing team bonuses. Thus, the employees can fulfill their capacities and complement individual talents and characteristics to enhance job performance. In the real estate market, brokers usually support each other by promoting the cases of various developers, introducing properties to clients for each other, and sharing information. Work accomplishments cannot be based exclusively on individualism. Factors of team operation should be considered, including team cooperation and team conflict.

In organizations and groups, members differ from each other in attitude and thought in work matters. Such diversity increases team creativity, decision-making quality, and job performance. In contrast, differing opinions and negative emotions in teams can result in conflict among employees. Hence, in team cooperation, employee interdependence is critical. If agreement and trust exist between members, then performance is upgraded considerably (Cleavenger et al., 2007). According to Mankin et al. (1996), the result and output of team effort are higher than those of individuals. Cooperation can trigger mutual assistance, resource exchange, and trust. Therefore, task interdependence in teams influences job performance.

Schwenk (1990) suggested that conflict helps predict performance, and Lewicki et al. (1992) showed that conflict encourages organizations and teams to maximize their efficacy. Research has 
also indicated that conflict can have both positive and negative impacts. When the impact is positive, it is known as task conflict, and when it is negative, it is called relationship conflict (Jehn, 1995; Amason, 1996).

In the case of some real estate companies, team cooperation leads real estate brokers to work more for the collective good of the team in order to enhance team collaboration. Close cooperation increases the team's job performance. Therefore, Mankin et al. (1996) suggested that performance as part of a team is more effective than individual performance. Team cooperation thus influences the performance of real estate brokers relatively. This study investigates the impact of team diversity, task interdependence, team conflict, and team cooperation on job performance, using real estate brokers as subjects.

This paper is organized as follows: Section 1 is the introduction, Section 2 proposes the research hypotheses, Section 3 describes the questionnaire design, Section 4 presents the collected data and descriptive statistics, Section 5 contains an analysis of the empirical results, Section 6 is the discussion, and Section 7 offers conclusions and suggestions.

\section{HYPOTHESES DEVELOPMENT}

\subsection{Hypotheses Related to Team Diversity}

Team diversity signifies the distribution of team members based on certain attributes. It exists on the team level and refers to differences between one team and another team instead of a comparison between individuals and others within groups (Jackson et al., 2003). When team members come from different work backgrounds, their belief structures tend to be different (Wieserma and Bantel, 1992). Belief structure refers to an individuals' cognition, view, and attitude toward objects that depend on the environment. For instance, members that have different belief structures also have different preferences and explanations for particular tasks (Wagner et al., 1984; Walsh, 1988). This inconsistency produces task conflict in teams.

Another type of conflicts are relationship conflicts. According to Pelled et al. (1999), there are two main factors in relationship conflicts. One is generalization, in which individuals unconsciously cluster and classify others. Once generalization exists in a group, people develop negative views toward other groups. The other factor is permeability, which refers to a change in attributes. For example, people can shift from one social status to another. When team diversity is not easily permeable, obstacles in communication among individuals of differing statuses can arise. In such cases, team members find it hard to put themselves in others' shoes. Finally, team members may be prejudiced against members of other statuses (Murray, 1989). Hostility toward different statuses or conflicts caused by differences in age or gender are relationship conflicts.

Regarding decision-making in teams, Harrison and Klein (2007) suggest that differences in position and opinion are based on individual values, beliefs, and attitudes. When the work backgrounds of group members differ significantly, task conflict arises and job performance is elevated. When race and working years differ greatly among team members, relationship conflict 
can arise, resulting in decreased job performance. According to Jehn et al. (1999), when information diversity is high among team members, task conflict increases. When value diversity is high, relationship conflict increases. Based on these studies, when team diversity increases, beliefs, cognition, and views among team members become inconsistent, and task conflict and relationship conflict arise. Hence, this study proposes $\mathrm{H} 1$ and $\mathrm{H} 2$ :

H1: Team diversity has a positive impact on task conflict.

H2: Team diversity has a positive impact on relationship conflict.

\subsection{Hypotheses Related to Task Interdependence}

Task interdependence includes group-work design, or group members' interaction and dependence on each other to accomplish work (Duffy et al., 2000). Team tasks refer to the essence, composition, and structure of tasks. At work, members must integrate and share their materials, information, and specialization with other members to attain the expected job performance (Cohen and Bailey, 1997). Regarding task interdependence, the execution result of one task depends on the performance of another (Milgrom and Roberts, 1990; 1995). When task interdependence is high, the task is more difficult, and members rely on others' work results.

Task interdependence is divided into positive interdependence and negative interdependence. Under positive interdependence, team members' personal goals are consistent with team goals, whereas negative interdependence means that team goals are different from individual goals. Under negative interdependence, team members may compete with one another, acquire the resources of other members, and even hinder the work of other team members, thereby resulting in task conflict (Deutsch, 1985). For resources, team members' interdependence increases. A high degree of interdependence enhances the risk of task conflict (Jelin, 1995). Based on these studies, we propose $\mathrm{H} 3$ :

H3: Task interdependence has a positive impact on task conflict.

When a team member performs one task without depending on other members, no interdependence exists (Pfeffer and Salancik, 1978). Team members perceive interpersonal conflict, which results in negative emotions (Jehn and Chatman, 2000). Wageman and Baker (1997)suggest that relationship conflict among team members decreases as task interdependence increases. Based on these studies, we propose $\mathrm{H} 4$ :

H4: Task interdependence has a negative impact on relationship conflict.

Social interdependence theory refers to the individuals' interaction within group situations. Positive team interdependence enhances individual responsibility toward other team members, such as accomplishing personal duties, helping other members complete their work, feeling bad about one's own and others' failures. Collective responsibility increases team members' motive to work (Matsui et al., 1987). There is consistent agreement on the positive effects of task interdependence on job performance (Van Der Vegt and Van De Vliert, 2002). (Stewart and 
Barrick, 2000) suggest that interdependence and task type influence the relationship between interdependence and job performance. Based on these studies, we propose $\mathrm{H} 5$ :

H5: Task interdependence has a positive impact on job performance.

In task interdependence, helping others is an important mechanism of cooperation, which is critical to enhancing the individual effectiveness of employees (Cleavenger et al., 2007). According to the empirical results of Pearce and Gregersen (1991), reciprocal task interdependence is positively related to employee responsibility. However, a negative correlation exists between task interdependence and responsibility. Wageman (1995) suggested that in teams with high task interdependence, members cooperate with each other, share information, and demonstrate other cooperative behavior to accomplish tasks. It enhances members' expectation of others' assistance. In addition, his research demonstrated a positive correlation between task interdependence and team cooperation. High interdependence results in increased team cooperation. Based on these studies, we propose H6:

H6: Task interdependence has a positive impact on team cooperation.

\subsection{Hypotheses Related to Task Conflict and Relationship Conflict}

Jehn and Mannix (2001) define conflict as a situation wherein individuals find others' desires to be difficult to achieve and others' expectations to be contradictory to and incompatible with their own. Communication or cooperation through the enhancement of collective benefits can avoid conflict. Jehn (1995) developed types of team conflict and divided conflict into task conflict and relationship conflict. Task conflict refers to situations wherein members have differing opinions toward the work content. It does not include strong, negative personal emotions. Relationship conflict refers to contradictions in interpersonal relationships. It is accompanied by frustration and anger and is related to members' personal preferences and emotions. To distinguish between task conflict and relationship conflict, Bono et al. (2002) suggested focusing on the characteristics of conflict. For instance, task conflict is associated with the perspective of a task and immediate action. Relationship conflict is related to emotions and affection.

Jehn (1995) and Amason (1996) suggested that when task conflict exists in teams, members express different opinions, clarify concepts, develop common consensus, accept decision-making, and increase knowledge sharing. Such a situation is similar to real conflict or cognitive conflict. When relationship conflict exists in teams, interpersonal conflict also arises, thereby increasing anxiety, anger, fear, frustration, and pressure among team members. Lee (2013) indicated that for real estate teams, limited resources and focus on individual performance results in competition among members. However, members should often share their commission after closing cases developed by others, and they cooperate with each other when introducing properties and sharing market information. Therefore, conflict and cooperation exist among members. Conflict is the mechanism whereby individuals rapidly trigger self-adjustment from behavior to emotional control. It results in team cooperation and accomplishes team goals. Based on previous studies, 
task conflict positively influences team cooperation, and relationship conflict negatively influences team cooperation. Therefore, we present $\mathrm{H} 7$ and $\mathrm{H} 8$ :

H7: Task conflict has a positive impact on team cooperation.

H8: Relationship conflict has a negative impact on team cooperation.

When cognitive conflict exists in teams, interaction among team members increases and helps teams solve problems. According to Putnam (1994), task conflict helps team members communicate with each other about potential problems, clarify misunderstandings, and exchange information. Task conflict can increase work identification and understanding. According to Amason (1996), when team members have different opinions during group interaction, discussions arise for making decisions. Team members express different opinions at work and in discussions, and task conflict helps enhance decision-making quality, understanding, commitment, as well as team members' emotional acceptance. Through task conflict, team members consider different opinions, thereby enhancing task cognition. Therefore, when task conflict in teams is high, decision-making performance increases.

Relationship conflict tends to produce negative emotions, therefore, it also hinders cognition (Sarason, 1984). When team members ponder on problems, they neglect important information and details. In situations of relationship conflict, team members harbor hostility. They do not share or exchange information, and they cannot listen to or accept others' opinions. With relationship conflict, team members must spend more time and effort on solving the conflict. This influences the quality of decision making and lowers team performance (Jehn, 1994). Based on these studies, task conflict positively influences performance, and relationship conflict decreases job performance. Therefore, we propose H9 and H10:

H9: Task conflict has a positive impact on job performance.

H10: Relationship conflict has a negative impact on job performance.

\subsection{Hypotheses Related to Team Cooperation}

Team cooperation is the outcome of members' interdependence and consistent goals (Jessup, 1990). Salas et al. (1992) suggested that team interaction significantly influences job performance and that the key factors of team interaction are negotiation, communication, and cooperation. Team cooperation demonstrates the importance of team training, which allows team members to perceive proper team interaction and increases overall job performance. Quick (1992) indicated that team cooperation results in higher efficiency in the use of resources. Team members encourage each other, respond immediately to problems, and solve problems collectively. They communicate publicly and sincerely, participate in making decisions that impact the team, thereby producing a more reliable work atmosphere and increasing their job performance. The empirical results of Mankin et al. (1996) demonstrate that compared to independent work, team operation positively and significantly influences performance. When team members have close relationships and share their goals with one another, such team cooperation heightens job performance in 
teams. According to Hackman (2002), when team members realize team goals, work progress, and task distribution, the overall team operation influences the team members' return and performance. Based on these findings, positive team cooperation enhances job performance. Therefore, we propose H11:

H11: Team cooperation has a positive impact on job performance.

The research model and hypotheses are illustrated in Fig. 1.

Figure-1. Establishment of the Research Framework and Hypotheses

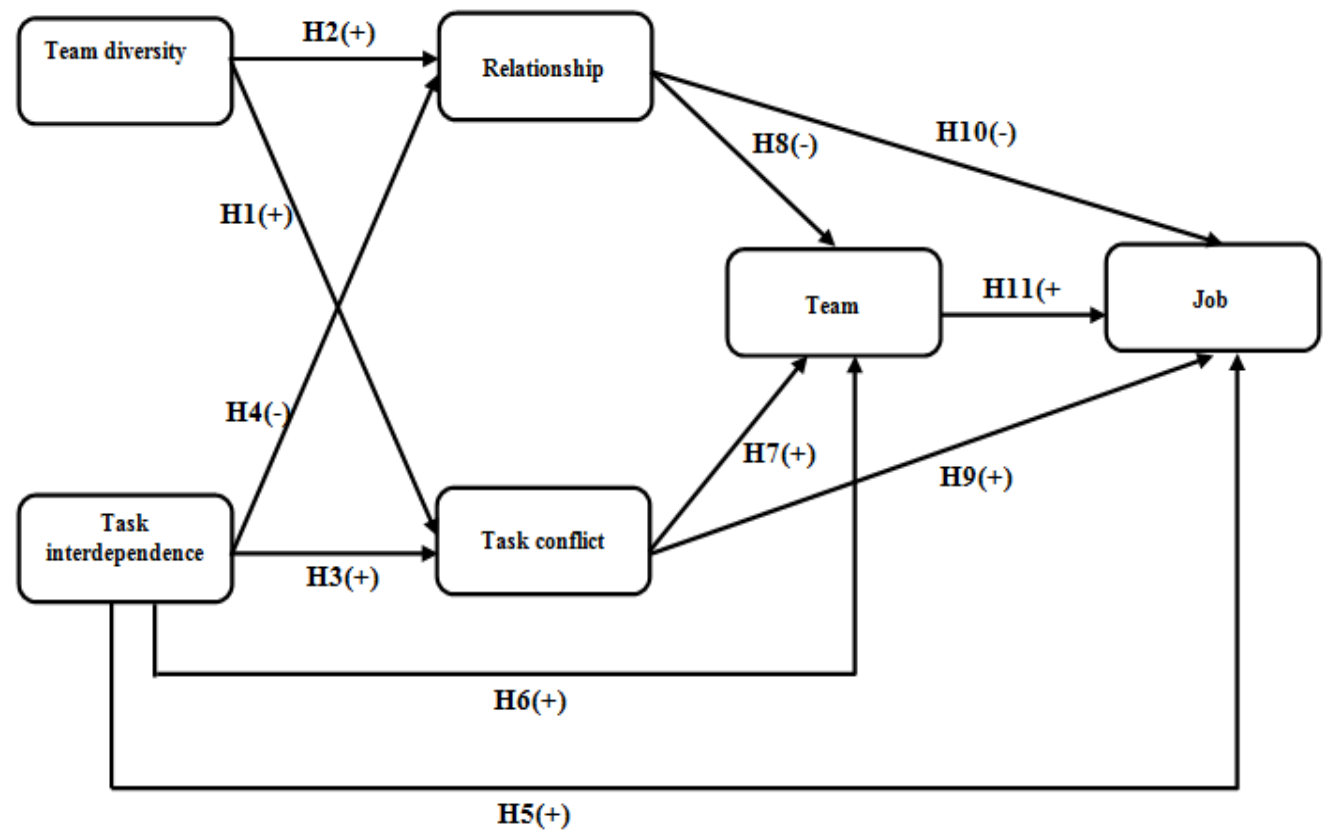

\section{QUESTIONNAIRE DEVELOPMENT}

The purpose of this study is to identify the effects of diversity, interdependence, and conflict on team performance. The contents of the questionnaire are divided into two parts. The first part concerns basic personal information, and the second part contains 6 latent variables: team diversity, task interdependence, relationship conflict, task conflict, team cooperation, and team performance. The questionnaire was scored using a Likert 5-point scale, ranging from 1 (strongly disagree) to 5 (strongly agree) (see the Appendix).

Team diversity is based on items developed by McGrath et al. (1995), and it includes a total of 4 items. Task interdependence is based on items developed by Jarvenpaa and Staples (2001), with a total of 4 items. Relationship conflict and task conflict are based on items developed by Jehn and Mannix (2001) and Pelled et al. (1999), with a total of 6 items. Team cooperation is based on items developed by Chatman and Flynn (2001), with a total of 4 items. Job performance is based on items developed by Campbell (1990) and Motowidlo and Van (1994), with a total of 6 items. In this study, the structural relationship among team diversity, task interdependence, 
relationship conflict, task conflict, team cooperation and job performance is the subjects' cognitive relationship.

\section{DATA COLLECTION AND DESCRIPTIVE STATISTICS OF SAMPLES}

\subsection{Sample and Data Collection}

Real estate brokers in Kaohsiung City were recruited as participants in this study. The real estate industry in Taiwan is classified under two systems: self-operating and chain. Generally, self-operating real estate companies are smaller in scale and system. They lack brand image, and it is difficult to survey them. Therefore, this study focuses on larger-scale, chain real estate companies that have complete systems and recognizable brand images. The survey was conducted from July 1 to August 31, 2013, and it includes chain real estate companies such as Pacific Realtor, Sinyi Realty, Century 21 Real Estate, H \& B Business group, Eastern Realty, Taiwan Realty Estate, Yungching Real Estate Agency, and others. A total of 568 questionnaires were distributed, with a total of 367 retrieved. After eliminating 5 invalid questionnaires, the researcher obtained 362 valid questionnaires, and the valid return rate was $98.6 \%$.

\subsection{Descriptive Statistics of Samples}

Among the retrieved samples, $58.3 \%$ are males and $41.7 \%$ are females. Most of the participants are aged 26-30 (21.0\%), followed by 31-35 (19.9\%), and 41-45 (14.4\%). Most of the participants (53.1\%) are married, with $43.3 \%$ unmarried. The majority of participants are university graduates (43.3\%), followed by those whose highest levels of education are senior high school and vocational school (27.2\%) and college (27.2\%). Regarding average personal annual income, most of the participants earned NTD 310,000-500,000 (24.1\%), followed by NTD 510,000-700,000 (23.8\%) and NTD 300,000 (23.2\%). Most of the participants (28.3\%) worked 4150 hours per week, followed by 51-60 hours per week (24.1\%).

\section{EMPIRICAL RESULTS}

SPSS/AMOS (v20.0) for Windows was used for data analysis. The structural equation model (SEM) was used for technical analysis and was divided into a measurement model and a structural model for descriptive purposes.

\subsection{Analysis of the Measurement Model}

The latent variable's composite reliability $(\mathrm{CR})$ is composed of the validity of all of its measurement variables, suggesting the internal consistency of the composite indicators. A higher level of validity suggests a higher level of consistency of these indicators. The CR of the latent variables in this research exceeds 0.6, which corresponds to Fornell and Larcker (1981) (Table 1); As shown in Table 1, the factor loadings of the measured variables are mostly above 0.70 and 
reaches a significant level, indicating that the questionnaire exhibits the required convergent validity.

The latent variable's average variance extracted (AVE) is to compute the explanatory power of the various measured variables of the latent variables on the latent variable. Therefore, a higher level of AVE indicates that the latent variable has a higher level of reliability and convergent validity. Furthermore, Fornell and Larcker (1981) stated that the AVE should be higher than 0.50. Table 1 shows that the AVE values are higher than the acceptable level of 0.50. Overall, the internal consistency of the scale is acceptable.

Table-1. Scale Reliability, Loadings, and Average Variance Extracted

\begin{tabular}{|c|c|c|c|c|}
\hline Variables & $\begin{array}{l}\text { Loadings } \\
\text { (standardized) }\end{array}$ & CR & AVE & $R^{2}$ \\
\hline Team diversity & & 0.841 & 0.755 & \\
\hline Diversity 1 & $0.778 * * *$ & & & \\
\hline Diversity 2 & $0.812^{* * *}$ & & & \\
\hline Diversity 3 & $0.676^{* * *}$ & & & \\
\hline Diversity 4 & 0.681 & & & \\
\hline Task interdependence & & 0.832 & 0.746 & \\
\hline Interdependence 1 & 0.559 & & & \\
\hline Interdependence 2 & $0.808^{* * *} *$ & & & \\
\hline Interdependence 3 & $0.775 * * *$ & & & \\
\hline Interdependence 4 & $0.717 * * *$ & & & \\
\hline Relationship conflict & & 0.932 & 0.907 & 0.045 \\
\hline Relationship 1 & $0.853^{* * *} *$ & & & \\
\hline Relationship 2 & $0.927 * * *$ & & & \\
\hline Relationship 3 & 0.918 & & & \\
\hline Task conflict & & 0.904 & 0.871 & 0.034 \\
\hline Task 1 & 0.829 & & & \\
\hline Task 2 & $0.823 * * *$ & & & \\
\hline Task 3 & $0.840 * * *$ & & & \\
\hline Team cooperation & & 0.754 & 0.715 & 0.312 \\
\hline Cooperation 1 & 0.519 & & & \\
\hline Cooperation 2 & 0.033 & & & \\
\hline Cooperation 3 & $0.886^{* * * *}$ & & & \\
\hline Cooperation 4 & $0.922 * * *$ & & & \\
\hline Job performance & & 0.957 & 0.887 & 0.393 \\
\hline Performance 1 & 0.804 & & & \\
\hline Performance 2 & $0.785^{* * *} *$ & & & \\
\hline Performance 3 & $0.787 * * *$ & & & \\
\hline Performance 4 & $0.851^{* * *} *$ & & & \\
\hline Performance 5 & $0.863 * * *$ & & & \\
\hline Performance 6 & $0.856^{* * * *}$ & & & \\
\hline
\end{tabular}

Note: $* p<0.10_{* * *} p<0.05_{\text {*** }} p<0.01$. The meaning of the measurement variables are shown in the Appendix.

In terms of discriminant validity, the square roots of the AVE of the latent variable must be larger than the correlation coefficients of the variables paired with the other variables (Fornell 
and Larcker (1981). This suggests that all components exhibit good discriminant validity. As shown in Table 2, for example, the square roots of task conflict and relationship conflict AVE values are 0.952 and 0.933 , respectively, which are greater than the correlation coefficients of task conflict and relationship conflict of 0.013 , suggesting a discriminant validity. The rest are similar by deduction. Therefore, the scales in this study have considerable levels of discriminant validity.

Table-2. Correlation Matrix of Latent Variables

\begin{tabular}{lcccccc}
\hline Team diversity & 0.869 & & & & & \\
\hline Task interdependence & -0.155 & 0.864 & & & & \\
\hline Task conflict & 0.075 & -0.001 & 0.952 & & & \\
\hline Relationship conflict & 0.094 & -0.089 & 0.013 & 0.933 & & \\
\hline Team cooperation & -0.077 & 0.142 & -0.021 & -0.103 & 0.846 & \\
\hline Job performance & -0.082 & 0.166 & 0.015 & -0.092 & 0.158 & 0.942 \\
\hline
\end{tabular}

Note: Thediagonal represents the square roots of the AVE of components.

\subsection{Analysis of the Structure Model}

\subsubsection{Overall Model Fit}

Bagozzi and Y (1988) indicated that the model fit cannot be determined by a single criterion or indicator alone and that the testing results of the overall model should also be considered. Regarding the overall theoretical model fit analysis, the absolute fit indicator $=775.815(\mathrm{p}<$ 0.000 ) reached the significant level of 0.05 , and the normal $=3.233$ is within the acceptable range. In addition, the goodness-of-fit index $(\mathrm{GFI})=0.851$, adjusted goodness of hit index (AGFI) $=$ 0.813 , normal fit index $(\mathrm{NFI})=0.858$, comparative fit index $(\mathrm{CFI})=0.896$, incremental fit index $(\mathrm{IFI})=0.897$, and root mean square residual $(\mathrm{RMR})=0.092$, standardized root mean square residual $($ RMSEA $)=0.079$ are mostly acceptable standard values. Overall, the theoretical model fit is acceptable.

\subsubsection{Empirical Results}

The empirical results of this study are shown in Fig. 2 and Table 3. The coefficient estimation of team diversity on task conflict is 0.245 , and it reaches a significance level of $1 \%$. Therefore, $\mathrm{H} 1$ is supported. The coefficient estimation of team diversity on relationship conflict is 0.167 , which reaches a significance level of $10 \%$. H2 is therefore supported. The coefficient estimation of task interdependence on task conflict is 0.116 , and it does not reach a significance level of $10 \%$. Therefore, H3 is not supported. The coefficient estimation of task interdependence on relationship conflict is -0.198 , and it does reach a significance level of $10 \%$. H4 is supported.

The coefficient estimation of task interdependence on job performance is 0.285 , which reaches a significance level of $1 \%$. H5 is therefore supported. The coefficient estimation of task interdependence on team cooperation is 0.423 , which reaches a significance level of $1 \%$. H6 is therefore supported. The coefficient estimation of task conflict on team cooperation is -0.036, which does not reach a significance level of $10 \%$. $\mathrm{H} 7$ is not supported. The coefficient estimation 
of relationship conflict on team cooperation is -0.089 , which reaches a significance level of $1 \%$. H8 is therefore supported.

The coefficient estimation of task conflict on job performance is 0.050 , which does not reach a significance level of $10 \%$. H9 is not supported. The coefficient estimation of relationship conflict on job performance is -0.019 , which does not reach a significance level of $10 \%$. H10 is not supported. The coefficient estimation of team cooperation on job performance is 0.524 , which does reach a significance level of $1 \%$. H1 1 is supported. According to these empirical results, aside from for $\mathrm{H} 3, \mathrm{H} 7, \mathrm{H} 9$ and $\mathrm{H} 10$, all of the other hypotheses are supported.

Figure-2. Analysis of the Structure Model

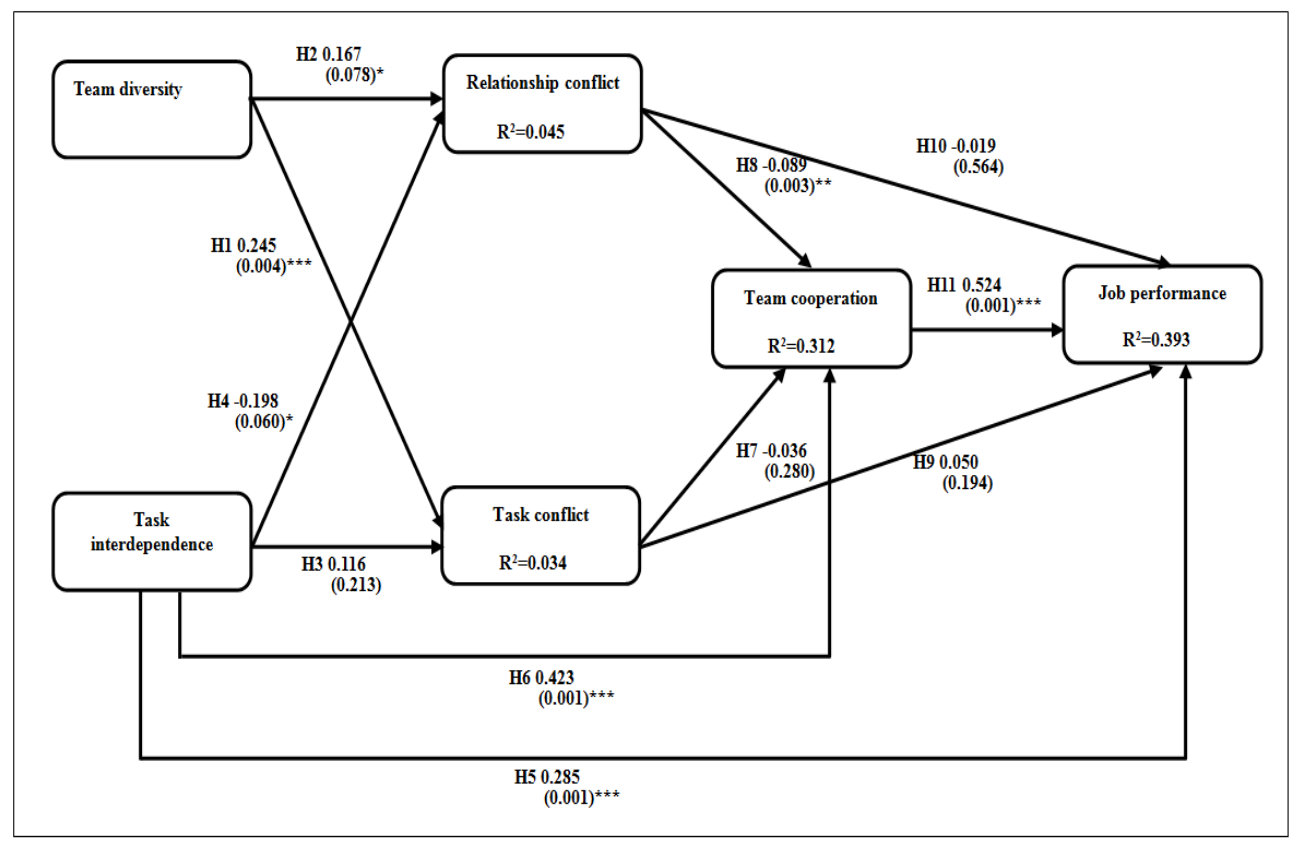

Note: $* p<0.10$.** $p<0.05$.*** $p<0.01$.

\section{DISCUSSION}

This study treats team diversity and task interdependence as exogenous variables and investigates the impact of task conflict, relationship conflict, and team cooperation on job performance, using the real estate industry as subject. In recent years, housing prices in Taiwan have increased steadily. Although the government has attempted to suppress the rise in real estate prices, it has not been completely successful. Real estate companies actively recruit talents as brokers. In this competitive industry, the turnover rate of labor is significantly high. Some brokers become top salespeople within a year, whereas others stay for only several months or even several days. Because the members of real estate branches come from different places and grew up in different environments, these aspects of their backgrounds can result in differing individual characteristics, such as personality, within the team. Furthermore, information within 
the real estate industry is usually not transparent, and members must often help each other. Work dependence and team diversity therefore impact the chain of team conflict, cooperation, and job performance.

Table-3. Hypotheses Testing Results

\begin{tabular}{|c|c|c|c|c|c|}
\hline Path & $\begin{array}{l}\text { Expected } \\
\text { sign }\end{array}$ & $\begin{array}{c}\text { Non- } \\
\text { standardized } \\
\text { coefficient }\end{array}$ & t-value & p-value & Hypotheses \\
\hline $\begin{array}{l}\text { H1 team diversity-> task } \\
\text { conflict }\end{array}$ & + & $0.245^{* * *} *$ & 2.859 & 0.004 & Supported \\
\hline $\begin{array}{l}\text { H2 team diversity-> } \\
\text { relationship conflict }\end{array}$ & + & $0.167^{*}$ & 1.763 & 0.078 & Supported \\
\hline $\begin{array}{l}\text { H3 task interdependence- } \\
>\text { task conflict }\end{array}$ & + & 0.116 & 1.245 & 0.213 & $\begin{array}{c}\text { Not } \\
\text { supported }\end{array}$ \\
\hline $\begin{array}{l}\text { H4 task interdependence- } \\
>\text { relationship conflict }\end{array}$ & - & $-0.198^{*}$ & -1.883 & 0.060 & Supported \\
\hline $\begin{array}{l}\text { H5 task interdependence- } \\
>\text { job performance }\end{array}$ & + & $0.285^{* * *}$ & 4.186 & 0.001 & Supported \\
\hline $\begin{array}{l}\text { H6 task interdependence- } \\
>\text { team cooperation }\end{array}$ & + & $0.423^{* * *} *$ & 6.142 & 0.001 & Supported \\
\hline $\begin{array}{l}\text { H7 task conflict-> team } \\
\text { cooperation }\end{array}$ & + & -0.036 & -1.081 & 0.280 & $\begin{array}{c}\text { Not } \\
\text { supported }\end{array}$ \\
\hline $\begin{array}{l}\text { H8 relationship conflict- } \\
>\text { team cooperation }\end{array}$ & - & $-0.089^{* * *}$ & -3.020 & 0.003 & Supported \\
\hline $\begin{array}{l}\text { H9 task conflict-> job } \\
\text { performance }\end{array}$ & + & 0.050 & 1.299 & 0.194 & $\begin{array}{c}\text { Not } \\
\text { supported }\end{array}$ \\
\hline $\begin{array}{l}\text { H10 relationship conflict- } \\
>\text { job performance }\end{array}$ & - & -0.019 & -0.557 & 0.564 & $\begin{array}{c}\text { Not } \\
\text { supported }\end{array}$ \\
\hline $\begin{array}{l}\text { H11 team cooperation-> } \\
\text { job performance }\end{array}$ & + & $0.524^{* * *} *$ & 5.860 & 0.001 & Supported \\
\hline
\end{tabular}

Notes: * $p<0.10$, $^{*} p<0.05,{ }^{*} * * 1 p<0.01$.

According to the empirical results of this study, $R^{2}$ of relationship conflict $=4.5 \%$. This indicates that the explained variance of team diversity and task interdependence on relationship conflict is $4.5 \%$. $R^{2}$ of task conflict $=3.4 \%$, which means that the explained variance of team diversity and task interdependence on relationship conflict is $3.4 \% . R^{2}$ of team cooperation = $31.2 \%$, which indicates that the explained variance of task conflict, task interdependence, and relationship conflict on team cooperation is $31.2 \% . R^{2}$ of job performance $=39.3 \%$, which means that the explained variance of task conflict, team cooperation, task interdependence, and relationship conflict on job performance is $39.3 \%$.

In teams with highly diverse members, task conflict and relationship conflict are more likely to exist. Pelled et al. (1999) suggest that when group members have high work-related background diversity, task conflict may arise. According to Jehn et al. (1999), when team members' information diversity is high, task conflict more likely arises. When team members' value diversity is high, relationship conflict is more likely to exist. This study demonstrates that 
diversity positively and significantly influences task conflict and relationship conflict. It supports the findings of Pelled et al. (1999) and Jehn et al. (1999).

According to the empirical results of this study, task interdependence and relationship conflict have an inverse relationship. In situations that contain relationship conflict, team members recognize interpersonal conflict, and this results in negative emotions (Jehn and Chatman, 2000). Wageman and Baker (1997) indicated that relationship conflict among team members decrease as task interdependence increases. This study demonstrates that task interdependence negatively and significantly influences relationship conflict. It supports the results of Jehn and Chatman (2000); Wageman and Baker (1997).

According to the empirical results of this study, task interdependence positively influences job performance. In social interdependence theory, Matsui et al. (1987) suggested positive interdependence among team members enhances the individual's responsibility toward other team members, such as accomplishing duties, helping other members complete their work, and feeling bad about one's own and others' failures. Responsibility enhances team members' work motive. This study demonstrates that task interdependence positively and significantly influences job performance, and supports the findings of Matsui et al. (1987).

Task interdependence also positively influences team cooperation. Wageman (1995) indicated that high task interdependence leads team-members to cooperate with each other, share information, and demonstrate other collaborative behavior to accomplish tasks. Task interdependence enhances members' expectations of others' assistance. A high level of interdependence results in higher team cooperation. This study demonstrates that task interdependence positively and significantly influences team cooperation. Therefore, it supports the finding of Wageman (1995).

A high level of conflict in interpersonal relationships impact team cooperation negatively. Sarason (1984) suggested that relationship conflict tends to result in negative emotions, thereby hindering the cognition of team members. When team members ponder on problems, they neglect important information and details. This study shows that relationship conflict negatively and significantly influences team cooperation. The finding of Sarason (1984) is therefore supported.

Team cooperation positively influences job performance. Quick (1992)suggested that team cooperation leads to a more efficient use of resources. Members encourage each other, respond immediately to problems and solve them collectively. They communicate publicly and sincerely, participate in making decisions that impact the team, thereby producing a more reliable work atmosphere and increasing their job performance. This study demonstrates that team cooperation positively and significantly influences job performance. The finding of Quick (1992) is supported. Based on previous research, task interdependence impacts task conflict positively. For instance, Jelin (1995) indicated that interdependence among team members increase resources. A high degree of interdependence enhances the risk of task conflict. This study demonstrates that task 
interdependence does not influence task conflict significantly. The research findings of Wageman and Baker (1997) and Jelin (1995) are therefore not supported.

Previous research has also found task conflict to impact team cooperation positively. For instance, Jehn (1995) and Amason (1996) suggested that task conflict in teams allows members to express different opinions, clarify concepts, reach a consensus, accept decision making, and share knowledge. This study demonstrates that task conflict does not influence team cooperation significantly. The research findings of Jehn (1995) and Amason (1996) are therefore not supported.

Task conflict has also been shown to have a positive impact on job performance. Putnam (1994) demonstrated that task conflict helps team members discuss potential problems, clarify misunderstandings, and exchange information. It can enhance team members' identification and understanding of tasks. This study shows that task conflict does not significantly influence job performance. The finding of Putnam (1994) is therefore not supported. Based on past research, relationship conflict negatively impacts job performance. Relationship conflict tends to result in negative emotions, hindering the cognition of team members (Sarason, 1984). When team members think about problems, they neglect important information and details. This study demonstrates that relationship conflict does not influence job performance significantly. The result of Sarason (1984) is therefore not supported.

\section{CONCLUSIONS AND SUGGESTIONS}

\subsection{Conclusions}

This study elucidates the main factors that influence the job performance of real estate brokers. Team diversity positively and significantly influences task conflict and relationship conflict. Teams with highly diverse members result in differences of opinion, task conflict, and relationship conflict. Task interdependence influences relationship conflict, job performance and team cooperation significantly. Relationship conflict has a negative and significant impact on team cooperation. Relationship conflict in teams can lead to interpersonal conflict and decrease team cooperation. Team cooperation has a positive and significant impact on job performance. Positive team cooperation enhances job performance. This study treats team diversity and task interdependence as exogenous variables and combines them with the job performance model. The empirical results of this study indicate good explanatory power.

The results of our study suggest that managers of real estate companies should focus on the impact of team diversity and relationship conflict on job performance. For instance, team members with similar educational, professional, and family backgrounds working together can avoid interpersonal problems. It lowers the risk of negative emotions and increases team cooperation and job performance. Likewise, real estate industries should enhance task interdependence, because it increases team cooperation and lowers relationship conflict. High task interdependence in teams leads to cooperation, information sharing and other collaborative 
behavior among team members to finish tasks (Wageman, 1995). For instance, different team members develop and sell properties and share the commission after sales. When introducing properties, team members cooperate with each other, thereby enhancing task interdependence and cooperation.

\subsection{Research Suggestions}

Previous academic research has explored team diversity, conflict, and performance. However, few studies have focused on the impact of team diversity on the performance of real estate brokers. This study treats team diversity as a latent variable. In the future, team diversity can be divided into other factors of performance, such as age, educational level, and sex, in order to investigate their impact on conflict and performance. In this study, the structural relationship among team diversity, task interdependence, relationship conflict, task conflict, team cooperation, and job performance refers to the subjects' cognitive relationship. Future research can divide the research level into individual and team levels and conduct hierarchical linear modeling to explore cross-level factors of individual performance in order to obtain a more complete research framework.

\section{Appendix}

Operational Definitions of Variables

\begin{tabular}{|c|c|c|}
\hline Constructs & Items & References \\
\hline Team diversity & $\begin{array}{l}\text { 1. Ages of members in the firm are highly similar. } \\
\text { 2. Educational backgrounds of members in the firm are highly similar. } \\
\text { 3. Professional knowledge of members in the firm is highly similar. } \\
\text { 4. Working years of members in the firm are highly similar. }\end{array}$ & McGrath et al. (1995) \\
\hline $\begin{array}{l}\text { Task } \\
\text { independence }\end{array}$ & $\begin{array}{l}\text { 1. I usually rely on my colleagues' assistance to accomplish the tasks. } \\
\text { 2. I usually rely on my colleagues' sharing of information/knowledge } \\
\text { for the task. } \\
\text { 3. I usually use my colleagues' information/knowledge for the task. } \\
\text { 4. My work performance relies on the efforts of my colleagues. }\end{array}$ & $\begin{array}{l}\text { Jarvenpaa and Staples } \\
(2001)\end{array}$ \\
\hline $\begin{array}{l}\text { Relationship } \\
\text { conflict }\end{array}$ & $\begin{array}{l}\text { 1. Members of the firm have interpersonal tension. } \\
\text { 2. Members of the firm tend to get angry at each other. } \\
\text { 3. Members of the firm are in emotional conflict. }\end{array}$ & $\begin{array}{l}\text { Jehn and Mannix (2001); } \\
\text { Pelled et al. (1999) }\end{array}$ \\
\hline Task conflict & $\begin{array}{l}\text { 1. In the team, members usually have conflict of ideas. } \\
\text { 2. Regarding tasks in the firm, members have different views } \\
\text { 3. Regarding tasks in the firm, members have opinion conflict. }\end{array}$ & \\
\hline $\begin{array}{l}\text { Team } \\
\text { cooperation }\end{array}$ & $\begin{array}{l}\text { In my firm, members are willing to sacrifice personal benefit for } \\
\text { team benefit. } \\
\text { 2. In my firm, members rarely cooperate with each other and they finish } \\
\text { tasks individually. } \\
\text { 3. In my firm, members often cooperate with each other. } \\
\text { 4. In my firm, members show a high degree of sharing. }\end{array}$ & $\begin{array}{l}\text { Chatman and Flynn } \\
(2001)\end{array}$ \\
\hline Job performance & $\begin{array}{l}\text { 1. I can effectively respond to clients' needs. } \\
\text { 2. I can effectively plan and arrange tasks. } \\
\text { 3. I have positive overall performance on capacity. } \\
\text { 4. When encountering obstacles at work, I try to overcome them and } \\
\text { finish the task. } \\
\text { 5. I cooperate with coworkers in the team. } \\
\text { 6. When coworkers encounter problems, I support and encourage them. }\end{array}$ & $\begin{array}{l}\text { Campbell } \\
\text { (1990);Motowidlo and } \\
\text { Van (1994) }\end{array}$ \\
\hline
\end{tabular}


Funding: This study received no specific financial support.

Competing Interests: The authors declare that they have no competing interests.

Contributors/Acknowledgement: All authors contributed equally to the conception and design of the study.

\section{REFERENCES}

Amason, A.C., 1996. Distinguishing the effects of functional and dysfunctional conflict on strategic decision making: Resolving a paradox for top management teams. Academy of Management Journal, 39(1): $123-148$.

Bagozzi, R.P. and Y. Y, 1988. On the evaluation of structural equation models. Journal of the Academy of Marketing Science, 16(1): 74-94.

Bono, J.E., T.L. Boles, T.A. Judge and K.J. Lauver, 2002. The role of personality in task and relationship conflict. Journal of Personality, 70(3): $311-344$

Campbell, J.P., 1990. Modeling the performance prediction problem in industrial and organizational psychology. Chicago: Rand McNally.

Chatman, J.A. and F.J. Flynn, 2001. The influence of demographic heterogeneity on the emergence and consequences of cooperative norms in work teams Academy of Management Journal, 44(5): 956 974.

Cleavenger, D., W.L. Gardner and K. Mhatre, 2007. Helping-seeking: Testing the effects of task interdependence and normativeness on employees propensity to seek help. Journal of Business and Psychology, $21(3):$ 331-359.

Cohen, S.G. and D.E. Bailey, 1997. What makes teams work: Group effectiveness research from the shop floor to the executive suite. Journal of Management, 23(3): 239-290.

Deutsch, M., 1985. Distributive justice: A social psychological perspective. New Haven: Yale University Press.

Duffy, M.K., J.D. Shaw and E.M. Stark, 2000. Performance and satisfaction in conflicted interdependent groups: When and how does self-esteem make a difference? Academy of Management Journal, 43(4): $772-782$.

Fornell, C. and D.F. Larcker, 1981. Evaluating structural equation models with unobservable variables and measurement error. Journal of Marketing Research, 18(1): 39-50.

Hackman, J.R., 2002. Leading teams: Setting the stage for great performances. Boston: Harvard Business School Press.

Harrison, D.A. and K.J. Klein, 2007. What's the difference? Diversity constructs as separation, variety, or disparity in organizations. Academy of Management Review, 32(4): 1199-1228.

Jackson, S.E., A. Joshi and N.L. Erhardt, 2003. Recent research on team and organizational diversity: SWOT analysis and implications. Journal of Management, 29(6): 801-830.

Jarvenpaa, S.L. and D.S. Staples, 2001. Exploring perceptions of organizational ownership of information and expertise. Journal of Management information Systems, 18(1): 151-183

Jehn, K.A., 1994. Enhancing effectiveness: An investigation of advantages and disadvantages of value-based intragroup conflict. International Journal of Conflict Management, 5(3): 223-238. 
Jehn, K.A., 1995. A multimethod examination of the benefits and detriments of intragroup conflict. Administrative Science Quarterly, 40(2): 256-282.

Jehn, K.A. and J.A. Chatman, 2000. The influence of proportional and perceptual conflict composition on team performance. The International Journal of Conflict Management, 11(1): 56-73.

Jehn, K.A. and E.A. Mannix, 2001. The dynamic nature of conflict: A longitudinal study of intragroup conflict and group performance. The Academy of Management Journal, 44(2): 238-251.

Jehn, K.A., G.B. Northcraft and M.A. Neale, 1999. Why difference make a difference: A field study of diversity, conflict, and performance in workgroups. Administrative Science Quarterly, 44(4): 741763.

Jelin, E., 1995. Building citizenship: A balance between solidarity and responsibility. In J. S. Tulchin (Ed.): The Consolidation of Democracy in Latin America. pp: 83-97.

Jessup, H.R., 1990. New roles in team leadership. Training and Development Journal, 44(11): 79-83.

Johnson, D.W. and R.T. Johnson, 1989. Cooperation and competition: Theory and research. Edina: Interaction Book Company.

Lee, C.C., 2013. Bonus and education heterogeneity effects on helping efforts. Bothalia Journal, 43(2): 159176.

Lewicki, R.J., S.E. Weiss and D. Lewin, 1992. Models of conflict, negotiation and third party intervention: A review and synthesis. Journal of Organizational Behavior, 13(3): 209-252.

Mankin, D., S.G. Cohen and T.K. Bikson, 1996. Teams and technology: Fulfilling the promise of the new organization. Boston: Harvard Business School Press.

Matsui, T., T. Kakayama and M. Onglatco, 1987. Effects of goals and feedback on performance in groups. Journal of Applied Psychology, 72(3): 407-415.

McGrath, J.E., J.L. Berdahl and H. Arrow, 1995. Traits, expectations, culture, and clout: The dynamics of diversity in work groups. Washington: American Psychological Association.

Milgrom, P. and J. Roberts, 1990. The economics of modern manufacturing: Technology, strategy, and organization. The American Economic Review, 80(3): 511-528.

Milgrom, P. and J. Roberts, 1995. Complementaries and fit strategy, structure, and organizational change in manufacturing. Journal of Accounting and Economics, 19(2/3): 179-208.

Motowidlo, S.J. and S.J.R. Van, 1994. Evidence that task performance should be distinguished from contextual performance. Journal of Applied Psychology, 79(4): 475-480.

Murray, A.I., 1989. Top management group heterogeneity and firm performance. Strategic Management Journal, 10(1): 125-141.

Pearce, J.L. and H.B. Gregersen, 1991. Task interdependence and extrarole behavior: A test of the mediating effects of felt responsibility. Journal of Apply Psychology, 76(6): 834-844.

Pelled, L.H., K.M. Eisenhard and K.R. Xin, 1999. Exploring the black box: An analysis of work group diversity, conflict, and performance. Administrative Science Quarterly, 44(1): 1-28.

Pfeffer, J. and G.R. Salancik, 1978. The external control of organizations: A resource dependence perspective. New York: Stanford University Press. 
Putnam, L.L., 1994. Productive conflict: Negotiation as implicit coordination. International Journal of Conflict Management, 5(3): 284-299.

Quick, T.L., 1992. Successful team building. New York: American Management Association.

Salas, E., T.L. Dickinson, S.A. Converse and S.I. Tannenbaum, 1992. Toward an understanding of team performance and training. In R.W. Swezey \& E. Salas (Eds.), Teams: Their training and performance. Norwood: Ablex. pp: 3-29.

Sarason, I.G., 1984. Stress, anxiety, and cognitive interface: Reactions to tests. Journal of Personality and Social Psychology, 46(4): 929-938.

Schwenk, C., 1990. Conflict in organizational decision making: An exploratory study of its effects in forprofit and not-for-profit organizations. Management Science, 36(4): 436-448.

Stewart, G.L. and M.R. Barrick, 2000. Team structure and performance: Assessing the mediating role of intra team process and the moderating role of task type. Academy of Management Journal, 43(2): 135-148.

Van Der Vegt, G. and E. Van De Vliert, 2002. Intragroup interdependence and effectiveness: Review and proposed directions for theory and practice. Journal of Managerial Psychology, 17(1): 50-67.

Wageman, R., 1995. Interdependence and group effectiveness. Administrative Science Quarterly, 4O(1): 145180.

Wageman, R. and G. Baker, 1997. Incentives and cooperation: The joint effects of task and reward interdependence on group performance. Journal of Organizational Behavior, 18(2): 139-158.

Wagner, W.G., J. Pfeffer and C.A.I. O'Reilly, 1984. Organizational demography and turnover in topmanagement groups. Administrative Science Quarterly, 29(1): 74-92.

Walsh, J.P., 1988. Selectivity and selective perception: An investigation of managers belief structures and information processing. The Academy of Management Journal, 31(4): 873-896.

Wellins, R.S., W.C. Byham and G.R. Dixon, 1994. Inside teams: How 20 world-class organizations are winning through teamwork. San Francisco: Jossey-Bass.

Wieserma, M.F. and K. Bantel, 1992. Top management team demography and corporate strategic change. The Academy of Management Journal, 35(1): 91-121.

Views and opinions expressed in this article are the views and opinions of the author(s), International Journal of Management and Sustainability shall not be responsible or answerable for any loss, damage or liability etc. caused in relation to/arising out of the use of the content. 